\title{
A NARRATIVE REVIEW ON THE CLINICAL PRACTICE GUIDELINES FOR THE MANAGEMENT OF OVERWEIGHT/OBESITY IN ADULTS
}

\author{
PALANISAMY AMIRTHALINGAM* \\ Department of Pharmacy Practice, Faculty of Pharmacy, University of Tabuk, Tabuk, Saudi Arabia. Email: amirpalanisamy15@gmail.com \\ Received: 18 November 2019, Revised and Accepted: 30 December 2019
}

\begin{abstract}
Obesity causes morbidity and mortality and also impairs the quality of life in humans. Clinical practice guidelines are well established to treat the obese population with or without comorbidities in all the age groups. Obesity in adults is a risk factor for metabolic disorders including Type-2 diabetes mellitus, hypertension, dyslipidemia, etc. Hence, this review has compared the various international clinical practice guidelines for the management of obesity in adults.
\end{abstract}

Four articles were included in the qualitative synthesis after the systematic review of the literature obtained from PubMed/MEDLINE and Web of Sciences. Diagnosis and various interventions including lifestyle, pharmacotherapy and bariatric surgery are compared for the management of obesity in adults.

The diagnosis is crucial since the criteria to determine overweight/obesity is still under debate due to inconclusive evidence. Various interventions including diet, exercise, behavior, drug therapy, and surgery are being recommended currently for the management of obesity. However, ethnicity and culture play a major role in diagnosis and also interventions. Moreover, personalizing the interventions according to the subject will make sense and offers success in the management of obesity.

Diagnosis and the intervention should be subject oriented based on ethnicity, culture and patient characteristics. In this connection, many longitudinal studies warranted to specify the diagnostic and management criteria for adults among the various ethnic populations across the world.

Keywords: Behavior, Clinical practice guidelines, Diet, Drug therapy, Exercise, Obesity.

(C) 2020 The Authors. Published by Innovare Academic Sciences Pvt Ltd. This is an open access article under the CC BY license (http://creativecommons. org/licenses/by/4. 0/) DOI: http://dx.doi.org/10.22159/ajpcr.2020.v13i2.36404

\section{INTRODUCTION}

Obesity is a major risk factor causing morbidity and mortality with the association of diabetes, hypertension, hyperlipidemia, obstructive sleep apnea, and osteoarthritis [1]. The weight that is higher than what is considered a healthy weight for a given height is described as overweight or obese. Body mass index (BMI) is used as a screening tool for overweight/obesity [2] and the same classified as overweight (BMI of $25 \mathrm{~kg} / \mathrm{m}^{2}$ or greater but $<30 \mathrm{~kg} / \mathrm{m}^{2}$ ), obesity $($ BMI $\geq 30$ ), and extreme obesity (BMI $\geq 40$ ) [3]. According to the World Health Organization report in $2016,>1.9$ billion adults (18 years and older) were overweight. Among these, over 650 million were obese. About $39 \%$ of adults aged 18 years and over were overweight, and $13 \%$ were obese. Most of the world's populations live in countries where overweight and obesity kill more people than underweight [2]. On the other hand, abdominal obesity which is a greater amount of fat in the abdomen or trunk compared with the hips and lower extremities has been associated with increased risk for Type 2 diabetes mellitus, hypertension, and heart disease in both men and women [4,5]. Abdominal obesity is commonly reported as a waist-tohip ratio, but it is most easily quantified by a single circumferential measurement obtained at the level of the superior iliac crest [6]. Thus, an overweight person with predominantly abdominal fat accumulation would be considered a "high" risk for these diseases irrespective of BMI criteria $[7,8]$. Various guidelines established already for the management of overweight/obesity for adults across the world based on BMI and waist circumference (WC); however, the recommended interventions from these guidelines yet to be compared. The objective of this narrative review is to compare the established guidelines for the management of overweight/obesity among the adults will provide the new insights into the health-care professionals for making appropriate intervention to improve the quality of life and also to prevent the complications.

\section{METHODS}

\section{Literature search}

The systematic approach [9] was followed to conduct a literature search on the current clinical practice guidelines on overweight/ obesity established by the numerous societies in the world. Several keywords have been used in the literature search including adults, bariatric surgery, BMI, clinical practice, diet, exercise, guidelines, nutrition therapy obesity, overweight, drug therapy, physical activity, surgery, weight loss in web of sciences, and Medline. The search was conducted during August 2019 and October 2019 to recruit recent guidelines for the management of overweight/obesity in adults. The articles were selected after the numerous reviews and the full search strategy is provided in Fig. 1.

\section{Criteria for the eligibility}

Articles included in this review have published in English and the most recent updated guidelines (2010-2019) from the various authorities in the developed countries to regulate the clinical practice guidelines for the management of overweight/obesity in the adults were considered as inclusion criteria. The remaining articles were considered as not eligible.

\section{Review and selection procedure}

The screening on the title was made initially to ensure the suitability for the review based on the inclusion criteria. The most recent update was included and the previously published clinical practice guidelines from the same authority were removed. Careful attentions have been 


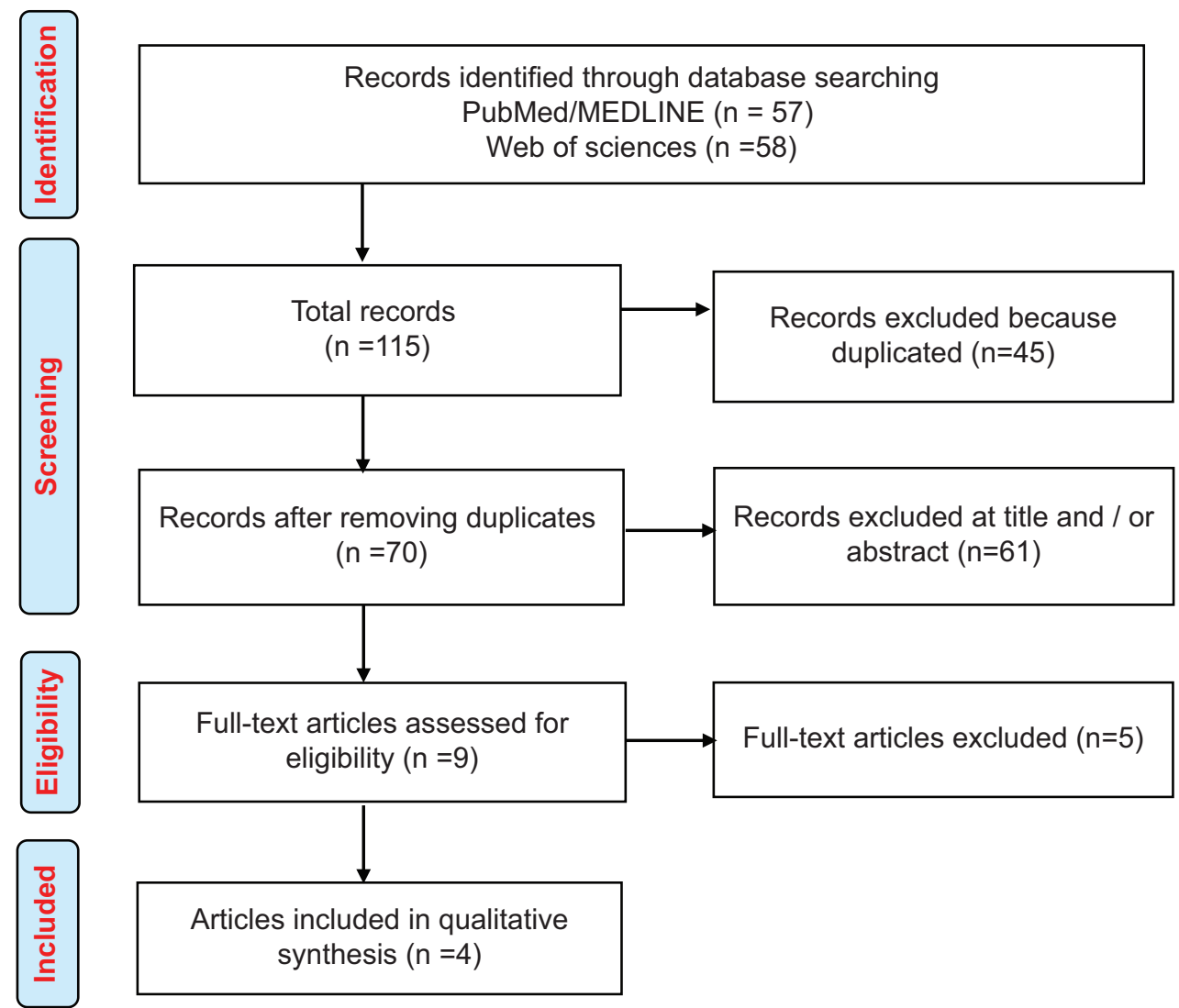

Fig. 1: Flowchart of included studies

given to rule out the duplication. The critical review has been made on the selected articles using the Critical Appraisal Skills Programme [10] which is appropriate to the study design.

\section{A critical appraisal of the identified articles}

This study was used to follow the narrative review format since the possibility of heterogeneity of the articles included by enabling the theoretical and contextual review of the topic. All the articles included have similar criteria to classify the overweight/obesity based on the BMI and also guidelines for the management of obesity in adults [11-14]

\section{RESULTS}

A total of 115 articles were identified after the systematic search after removing the duplicates it was around 70 . Then, nine abstracts have been retained after the screening based on the eligibility criteria and

Table 1: Management guidelines for weight loss in obesity based on BMI in adults

\begin{tabular}{lll}
\hline BMI & AACE/ACE & NHMRC \\
\hline $\begin{array}{l}\text { Overweight BMI: } 25-29.9 \\
\text { Obesity BMI: } \geq 30\end{array}$ & $*$ & $* * *$ \\
\hline AACE/ACE: American Association of Clinical Endocrinologists and American \\
College of Endocrinology, BMI: Body mass index, NHMRC: National Health and \\
Medical Research Council. ${ }^{*}$ Lifestyle therapy - reduce calorie healthy meal \\
plan/physical activity/behavioral interventions, ${ }^{* *}$ weight loss medications, \\
consider if lifestyle therapy fails to prevent progressive weight gain (BMI \\
$>27$ ), bariatric surgery if BMI $\geq 35,{ }^{* * *}$ lifestyle change - reduced energy intake, \\
physical activity, and behavioral change; weight loss medication if BMI $>28$, \\
bariatric surgery if BMI $>40$
\end{tabular}

the same selected for critical appraisal was made on the full text and finally, four retained and included in this review (Fig. 1).

All the selected articles were published by the authorities belong to the developed countries including the American Association of Clinical Endocrinologists and American College of Endocrinology (AACE/ACE; last updated on 2016) [11], European Practical and Patient-Centred Guidelines (last updated on 2019) [12], National Institute for Health and Care Excellence (NICE; last updated on 2014) [13], and National Health and Medical Research Council (NHMRC; last updated on 2013) [14].

\section{Guidelines for the management of overweight and obesity}

All the guidelines concerning with the management of overweight/ obesity among the adults and met similar criteria about the BMI classification. The NHMRC [14] and AACE/ACE [11] recommendations based on the BMI (i.e., overweight BMI: 25-29.9; obesity BMI: $\geq 30$ ); however, weight loss medications (if BMI $>27$ [11] and/or BMI > 28 [14]) and bariatric surgery (if BMI $\geq 35$ [11] and/or BMI $>40$ [14]) were recommended in addition to the lifestyle changes including diet, physical activity, and behavioral changes (Table 1).

Interestingly, WC is the additional criteria in the European Practical and Patient-Centred Guidelines [12] and NICE [13]. The recommendations have been according to both BMI and WC, however, European Practical and Patient-Centred Guidelines restricted the WC with two categories (i.e., men $<94 \mathrm{~cm}$ and women $<80 \mathrm{~cm}$; men $\geq 94 \mathrm{~cm}$ and women $\geq 80 \mathrm{~cm}$ ) [15]. On the other hand, the NICE categorized the WC in three categories (for men, WC of $<94 \mathrm{~cm}$ is low, $94-102 \mathrm{~cm}$ is high, and more than $102 \mathrm{~cm}$ is very high; for women, WC of $<80 \mathrm{~cm}$ is low, $80-88 \mathrm{~cm}$ is high, and more than $88 \mathrm{~cm}$ is very high). Both recommending diet and physical activity \pm drugs in obesity Grade II (i.e., BMI $>35-39.9$ ) and also diet and physical activity \pm drugs \pm surgery for obesity Grade III (i.e., BMI $\geq 40$ ) 
Table 2: Management guidelines for obesity based on BMI with waist circumference in adults

\begin{tabular}{|c|c|c|c|c|c|}
\hline \multirow[t]{2}{*}{ Variable } & \multicolumn{2}{|c|}{$\begin{array}{l}\text { European Guidelines for Obesity } \\
\text { Management in Adults }\end{array}$} & \multicolumn{3}{|c|}{ National Institute for Health and Care Excellence } \\
\hline & $\begin{array}{l}\text { Men }<94 \mathrm{~cm} \text {, } \\
\text { women }<80 \mathrm{~cm}\end{array}$ & $\begin{array}{l}\text { Men } \geq 94 \mathrm{~cm}, \\
\text { women } \geq 80 \mathrm{~cm}\end{array}$ & $\begin{array}{l}\text { Men }<94 \mathrm{~cm} \text {, } \\
\text { women }<80 \mathrm{~cm}\end{array}$ & $\begin{array}{l}94-102 \mathrm{~cm} \text { in men, } \\
80-88 \mathrm{~cm} \text { in women }\end{array}$ & $\begin{array}{l}>102 \mathrm{~cm} \text { in men, } \\
>88 \mathrm{~cm} \text { in women }\end{array}$ \\
\hline $\begin{array}{l}\text { Overweight or pre-obese state; } \\
\text { BMI 25-29.9 }\end{array}$ & ** & ** & * & $* *$ & $* *$ \\
\hline Obesity Grade I; BMI 30.0-34.9 & $* *$ & $* * *$ & $* *$ & $* *$ & $* *$ \\
\hline Obesity Grade III; BMI $\geq 40$ & $* * * *$ & $* * * *$ & $* * * *$ & $* * * *$ & $* * * *$ \\
\hline
\end{tabular}

${ }^{*}$ General advice on healthy weight and diet, ${ }^{* *}$ diet and physical activity, ${ }^{* * *}$ diet and physical activity \pm drugs, ${ }^{* * * *}$ diet and physical activity \pm drugs \pm surgery. BMI: Body mass index

Table 3: Guidelines for the lifestyle intervention in the management of obesity in adults

\begin{tabular}{lllll}
\hline Interventions & AACE/ACE & NHMRC & $\begin{array}{l}\text { European Guidelines for } \\
\text { Obesity Management in } \\
\text { Adults }\end{array}$ & $\begin{array}{l}\text { National Institute for Health and } \\
\text { Care Excellence }\end{array}$ \\
\hline Diet plan & $\begin{array}{l}\text { Mediterranean, } \\
\text { DASH, low } \\
\text { carbohydrate, low } \\
\text { fat, volumetric, } \\
\text { high protein, }\end{array}$ & $\begin{array}{l}\text { Wide variety of } \\
\text { nutritious foods as } \\
\text { recommended in the } \\
\text { current Australian } \\
\text { vietary Guidelines [15] }\end{array}$ & $\begin{array}{l}\text { Decrease energy density of } \\
\text { food; increase vegetables } \\
\text { and eat two portions of } \\
\text { fruit per day; decrease fatty } \\
\text { foods, especially saturated } \\
\text { fat; decrease refined } \\
\text { carbohydrates, sugar, and } \\
\text { sweetened beverages }\end{array}$ \\
& & & -
\end{tabular}

energy intake/day

in kcal

Physical activity

with time duration

per week

\section{Voluntary aerobic} physical activity* performed on 3-5 separate days per

Strategies for week

$1-11$

behavioral change $^{\dagger}$
Moderate-intensity activity* vigorous activity**

$1,2,4,5,6,9$
Aerobic exercises* and ordinary/daily physical activity
Moderate or greater intensity physical activity* on 5 or more days a week. The activity can be in one session or several sessions lasting 10 min or more $1,2,4,5,6,9,11,13,14,15,16$

${ }^{*} \sim 150 \mathrm{~min} / \mathrm{w},{ }^{* *} 75-150 \mathrm{~min} / \mathrm{w}$, DASH: Dietary approach to stop hypertension, ${ }^{\dagger}$ strategies for behavioral change. $\left({ }^{1}\right.$ Self-monitoring, ${ }^{2}$ goal setting, ${ }^{3}$ education, ${ }^{4}$ problemsolving, ${ }^{5}$ stimulus control, ${ }^{6}$ behavioural contracting/behavior and progress, ${ }^{7}$ stress reduction, ${ }^{8}$ psychological support/evaluation, ${ }^{9} \mathrm{cognitive}$ restructuring, ${ }^{10} \mathrm{motivational}$ interviewing, ${ }^{11}$ mobilization of social support/slowing rate of eating ensuring social support, ${ }^{12}$ cognitive behavioral therapy, ${ }^{13}$ assertiveness, ${ }^{14} \mathrm{reinforcement}$ of changes,

${ }^{15}$ relapse prevention, ${ }^{16}$ strategies for dealing with weight regain)

irrespective of the WC. Diet and physical activity were recommended for obesity Grade I (i.e., BMI >30.0-34.9) in the NICE guidelines irrespective of the WC. Although, diet and physical activity were recommended by European guidelines among the obesity Grade I with the normal WC (men $<94 \mathrm{~cm}$ and women $<80 \mathrm{~cm}$ ), drug therapy is recommended along with the diet and physical activity in the increasing WC (Table 2).

Guidelines for the lifestyle intervention in the management of obesity in adults

The guidelines included in the review generally recommending diet, physical activity, and behavioral change under lifestyle intervention (Table 3).

Diet

Reduction in calorie [13], carbohydrate [11,12], and fat [11] diet generally recommended and encouraged to take more vegetables, fruits, and protein $[11,12]$ and the NHMRC recommends to follow the Australian Dietary Guidelines [16] also substantiates the other guidelines. However, the Mediterranean and Dietary Approaches to Stop Hypertension (DASH) emphasized by the AACE/ACE [11]. Reduction in weight intake/day ranges from 500 to $750 \mathrm{kcal}$ according to the AACE/ACE [11] and 600 according to the NHMRC [14] and NICE guidelines [13].

\section{Physical activity}

Aerobic exercise and moderate to greater/vigorous physical activity are recommended for approximately $\sim 150 \mathrm{~min} / \mathrm{w}$ in the management of overweight/obesity [11-14]. In addition, European guidelines recommended physical activity daily [12].

\section{Behavioral change}

The recommendation regarding the behavioral change (Table 3) includes the self-monitoring, goal setting, education, problem-solving, stimulus control, behavioral contracting/behavior and progress, stress reduction, psychological support/evaluation, cognitive restructuring, motivational interviewing, mobilization of social support/slowing rate of eating ensuring social support, cognitive behavioral therapy, assertiveness, reinforcement of changes, relapse prevention, and strategies for dealing with weight regain [11-14].

Guidelines for the pharmacological intervention in the management of obesity in adults

Orlistat is the only medication recommended unanimously [11-14]; however, liraglutide [11,12], phentermine/topiramate extended release (ER) [11], and bupropion/naltrexone [12] were the other choices for the management of overweight/obesity in the adults (Table 4).

\section{DISCUSSION}

Overweight/obesity is the known risk factor for diabetes $[17,18]$, hypertension [17,19], dyslipidemia [20], cardiovascular diseases (CVDs) [21,22], stroke [23], asthma [24,25], gastroesophageal reflux disease [26], cancer [27], and osteoarthritis [28], especially in the 
Table 4: Guidelines for the pharmacological intervention in the management of obesity in adults

\begin{tabular}{lllll}
\hline Interventions & AACE/ACE* & NHMRC** & $\begin{array}{l}\text { European Guidelines for Obesity } \\
\text { Management in Adults*** }\end{array}$ & $\begin{array}{l}\text { National Institute for Health and Care } \\
\text { Excellence }\end{array}$ \\
\hline $\begin{array}{l}\text { Pharmacologic } \\
\text { therapy }\end{array}$ & $\begin{array}{l}\text { Orlistat Phentermin } \\
\text { /topiramate ER } \\
\text { Liraglutide }\end{array}$ & Orlistat & $\begin{array}{l}\text { Orlistat Bupropion/naltrexone } \\
\text { Liraglutide }\end{array}$ & Orlistat \\
\hline
\end{tabular}

*Preferred weight loss medication: Individualization therapy, **treating overweight (with comorbidities) and obesity that has been evaluated for long-term safety,

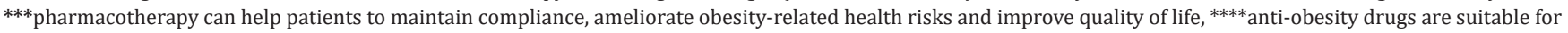
patients with BMI $>30 \mathrm{~kg} / \mathrm{m}^{2}$ or with BMI $>27 \mathrm{~kg} / \mathrm{m}^{2}$ with comorbidities. BMI: Body mass index, ER: Extended release

adults, it decreases the life span from 5.8 and 7.1 years compared with the non-obese population [29]. Hence forth, the amendment of clinical practice guidelines needs to be ensured to minimize the morbidity and mortality in this regard. Lifestyle modifications including diet, physical activity, and behavioral changes were highly recommended for BMI $>25[11,14]$ with especially $W C \geq 94 \mathrm{~cm}$ in male and $\geq 80 \mathrm{~cm}$ in the female [12,13]. Recent findings advocating that both BMI and WC should be considered for monitoring obesity, especially in hypertensive [30,31], however, WC is the significant predictor for type-2 diabetes mellitus [32-34] than the other anthropometric measurement. On the other hand, controversy findings have been reported about the association of cardiometabolic markers with the anthropometric measurements by establishing its association with the WC alone in Canadian adults [35] and both BMI and WC in Chinese adults [36]. However, the criteria to determine the metabolic syndrome by both the International Diabetes Federation [37] and the National Cholesterol Education Program [38] are consistent with both BMI and WC about the anthropometric measurements concerning obesity. In this regard, various research findings were established recently about diet, physical activity, behavioral intervention, and drug therapy.

\section{Diet}

The recent studies encourage the intake of Mediterranean diet [39,40] and DASH as part of obesity management [41] dietary approaches to the treatment of obesity [42] and also mindful eating intervention [43] has already been established. Reduction in energy intake/day in kcal is highly encouraged by the clinical practice guidelines for obese adults $[11,13,14]$. However, the recent guidelines encouraging a very low-calorie diet as a part of a multicomponent weight management strategy, for people who are obese and who have a clinically assessed need to rapidly lose weight [13]. Energy deficit is the primary challenge during this intervention [44] which can be minimized by optimizing the diet according to the individuals [45] with the careful consideration of target risk factors [44]. Moreover, this type of intervention encourages the patient to tailor and personalize their dietary patterns to reduce energy intake for sustainable weight loss [46].

\section{Physical activity}

Physical activity with dietary intervention is highly effective in weight loss $[47,48]$, especially to minimize the CVD risk factors [49-51]. Approximately $150 \mathrm{~min} / \mathrm{w}$ physical activity is recommended by all the clinical practice guidelines included in this review [11-14]. The vigorous activity needs $75-150 \mathrm{~min} / \mathrm{w}$ [14] is recommended to implement gradually with the initial $4-12 \mathrm{w}$ of moderate-intensity activity if an individual with a BMI $<35$ [52]. Evidence that suggests total daily accumulated energy expenditure is the strongest predictor of weight loss in obesity $[53,54]$. Cardiorespiratory fitness emphasizing the reduction in the mortality among the obese population with the independent cardiometabolic risk factors including fat deposition [55-57], blood pressure [58,59], and glycemic control $[59,60]$. Various strategies have been explored recently including moderate-to-vigorous-intensity physical activity [61-63], comprehensive behavioral intervention including 10,000 steps/d [64], wearable devices in the comprehensive weight loss intervention $[65,66]$, and comprehensive weight loss intervention through a telephone call with a health coach $[67,68]$. Based on the above findings, the time duration, frequency, and type of exercise need to individualize by considering the $\mathrm{BMI} / \mathrm{WC}$ and other risk factors in the individual.

\section{Behavioral interventions}

Self-monitoring, goal setting, problem-solving, stimulus control, behavioral contracting/behavior and progress, and cognitive restructuring are common behavioral interventions recommended by the clinical practice guidelines (Table 3) $[11,13,14]$. Behavioral intervention through counseling promotes the dietary habit and physical activity among the adults irrespective of the cardiac risk factors [69-71]. However, the most recent randomized controlled trial found no significant changes in BMI using low-intensity weight loss programs and also recommended an incremental dose in the intervention [72]. Digitalbased approach including health behavior change interventions [73] offers specifically the behavior change techniques [74] and modes of delivery may individualize the need for behavioral changes $[75,76]$. This is further needed to be standardized with the relevant intervention components in promoting chronic weight management [77-79].

\section{Drug therapy}

Orlistat, lorcaserin, phentermine/topiramate ER, naltrexone/ bupropion, and liraglutide $3 \mathrm{mg}$ are already approved by the FDA $[80,81]$. Drug therapy in the management of obesity associated with modest weight benefits (5-10\% range) with a significant impact on cardiovascular risk [82]. However, drug therapy can be considered as an alternative in such cases neither achieved weight loss with diet and physical activity nor eligible for bariatric surgery. The best approach is to individualizing drugs with specific lifestyle interventions [83] and/or behavioral intervention [82] according to the obese adult. Anti-obesity drugs aimed at limited energy absorption by inhibiting and blocking gastric and pancreatic lipases or amylases, microsomal triglyceride in protein, diacylglycerol-0-acetyltransferase/ monoglycerol-0-acyltransferase, and low-affinity sodium-dependent glucose cotransporter-2 (SGLT2) [84-86]. The emerging drugs under investigation including cetilistat (a lipase inhibitor), dapagliflozin (an SGLT2 inhibitor), empagliflozin (an SGLT2 inhibitor), and dirlotapide (an MTP inhibitor) belong to this group appearing as potential drugs by reducing absorption [87].

\section{Surgical intervention}

Surgical intervention may be considered if BMI $>40$ [12-14] or $\geq 35$ [11]; however, the criteria are $>30$ if already made multiple attempts on weight reduction [88]. In addition, BMI $>35$ associated with the comorbid conditions indicated for bariatric surgery [89]. Significant reduction in mortality from $30 \%$ to $50 \%$ due to CVD deaths [90] is achieved with the bariatric surgery as compared to lifestyle intervention [91]. However, perioperative mortality $(<0.3 \%)$ risk is associated with bariatric surgery [92] and the incidence rate is depending on the follow-up, complications, bariatric procedure, individual patient characteristics, etc. [93]. Henceforth, still more research is warranted to examine the long-term outcomes of bariatric surgery in the heterogeneous population [94-98].

\section{CONCLUSION}

The selection of anthropometric measurements to determine obesity plays a crucial role initially in the management of obesity since controversy findings reported in this regard. A combination of both the BMI and WC offers additional benefits to classify overweight/obesity; still, ethnicity-based classification is warranted to establish the same. Although obesity has several management options, this should be 
optimized according to the patient. The clinician should consider the comorbidities/family history with any metabolic risk factors among the adult population for the prevention of cardiovascular disorder and other complications due to obesity.

\section{AUTHOR'S CONTRIBUTIONS}

The author declares that this entire work was done by the author named in this article.

\section{CONFLICTS OF INTEREST}

The author declares no conflicts of interest.

\section{REFERENCES}

1. Haslam DW, James WP. Obesity. Lancet 2005;366:1197-209.

2. World Health Organization. WHO Report on Obesity and Overweight Published $16^{\text {th }}$ February 2018. Available from: https://www.who.int/ news-room/fact-sheets/detail/obesity-and-overweight

3. Fryar CD, Carroll MD, Ogden CL. Prevalence of Overweight, Obesity, and Extreme Obesity among Adults aged 20 and over: The United States, 1960-1962 Through 2013-2014. In: National Center for Health Statistics. Available from: https://www.cdc.gov/nchs/data/hestat/ obesity_child_15_16/obesity_child_15_16.pdf.

4. Janssen I, Katzmarzyk PT, Ross R. Waist circumference and not body mass index explains obesity-related health risk. Am J Clin Nutr 2004;79:379-84

5. Balkau B, Deanfield JE, Després JP, Bassand JP, Fox KA, Smith SC Jr., et al. International Day for the Evaluation of Abdominal Obesity (IDEA): A study of waist circumference, cardiovascular disease, and diabetes mellitus in 168,000 primary care patients in 63 countries. Circulation 2007;116:1942-51.

6. Clinical guidelines on the identification, evaluation, and treatment of overweight and obesity in adults the evidence report. National Institutes of Health. Obes Res 1998;6 Suppl 2:51S-209.

7. Grundy SM. Metabolic syndrome scientific statement by the American Heart Association and the National Heart, Lung, and Blood Institute. Arterioscler Thromb Vasc Biol 2005;25:2243-4.

8. Jacobson TA, Ito MK, Maki KC, Orringer CE, Bays HE, Jones PH, et al. National lipid association recommendations for patient-centered management of dyslipidemia: Part 1--full report. J Clin Lipidol 2015;9:129-69.

9. PRISMA. Transparent Reporting of Systematic Reviews and Metaanalyses. Available from: http://www.prisma-statement.org.

10. CASP. Critical Appraisal Skills Programme. Available from: https:// www.casp-uk.net.

11. Garvey WT, Mechanick JI, Brett EM, Garber AJ, Hurley DL, Jastreboff AM, et al. American association of clinical endocrinologists and American college of endocrinology comprehensive clinical practice guidelines for medical care of patients with obesity. Endocr Pract 2016;22 Suppl 3:1-203

12. Durrer Schutz D, Busetto L, Dicker D, Farpour-Lambert N, Pryke R, Toplak $\mathrm{H}$, et al. European practical and patient-centred guidelines for adult obesity management in primary care. Obes Facts 2019;12:40-66.

13. Obesity: Identification, Assessment, and Management. National Institute for Health and Care Excellence; 2014. Available from: https:// www.nice.org.uk/guidance/cg189/resources/obesity-identificationassessment-and-management-pdf-35109821097925.

14. Clinical Practice Guidelines for the Management of Overweight and Obesity in Adults, Adolescents and Children in Australia. National Health and Medical Research Council; 2013. Available from: http:// www.c:/users/058316/downloads/n57-obesity-guidelines-\%20(3).pdf.

15. Yumuk V, Tsigos C, Fried M, Schindler K, Busetto L, Micic D, et al. European guidelines for obesity management in adults. Obes Facts 2015;8:402-24.

16. Eat for Health; Australian Dietary Guidelines Summary. National Health and Medical Research Council; 2013. Available from: https:// www.eatforhealth.gov.au/sites/default/files/files/the_guidelines/n55a australian dietary guidelines summary book.pdf.

17. Babu GR, Murthy GV, Ana Y, Patel P, Deepa R, Neelon SE, et al. Association of obesity with hypertension and Type 2 diabetes mellitus in India: A meta-analysis of observational studies. World J Diabetes 2018:9:40-52

18. Keskin M, Kurtoglu S, Kendirci M, Atabek ME, Yazici C. Homeostasis model assessment is more reliable than the fasting glucose/insulin ratio and quantitative insulin sensitivity check index for assessing insulin resistance among obese children and adolescents. Pediatrics 2005;115:e500-3.

19. Huang Z, Willett WC, Manson JE, Rosner B, Stampfer MJ, Speizer FE, et al. Body weight, weight change, and risk for hypertension in women. Ann Intern Med 1998;128:81-8.

20. Singh AK, Singh SK, Singh N, Agrawal N, Gopal K. Obesity and dyslipidemia. Int J Biol Med Res 2011;2:824-8.

21. Csige I, Ujvárosy D, Szabó Z, Lőrincz I, Paragh G, Harangi M, et al. The impact of obesity on the cardiovascular system. J Diabetes Res 2018;2018:3407306

22. Wilson PW, D'Agostino RB, Sullivan L, Parise H, Kannel WB. Overweight and obesity as determinants of cardiovascular risk: The Framingham experience. Arch Intern Med 2002;162:1867-72.

23. Song YM, Sung J, Davey Smith G, Ebrahim S. Body mass index and ischemic and hemorrhagic stroke: A prospective study in Korean men. Stroke 2004;35:831-6.

24. Weiss ST, Shore S. Obesity and asthma: Directions for research. Am J Respir Crit Care Med 2004;169:963-8

25. Guerra S, Wright AL, Morgan WJ, Sherrill DL, Holberg CJ, Martinez FD. Persistence of asthma symptoms during adolescence: Role of obesity and age at the onset of puberty. Am J Respir Crit Care Med 2004;170:78-85.

26. Hampel H, Abraham NS, El-Serag HB. Meta-analysis: Obesity and the risk for gastroesophageal reflux disease and its complications. Ann Intern Med 2005:143:199-211.

27. Aspden RM, Scheven BA, Hutchison JD. Osteoarthritis as a systemic disorder including stromal cell differentiation and lipid metabolism. Lancet 2001;357:1118-20.

28. Basen-Engquist K, Chang M. Obesity and cancer risk: Recent review and evidence. Curr Oncol Rep 2011;13:71-6.

29. Peeters A, Barendregt JJ, Willekens F, Mackenbach JP, Al Mamun A, Bonneux L, et al. Obesity in adulthood and its consequences for life expectancy: A life-table analysis. Ann Intern Med 2003;138:24-32.

30. Kuciene R, Dulskiene V. Associations between body mass index, waist circumference, waist-to-height ratio, and high blood pressure among adolescents: A cross-sectional study. Sci Rep 2019;9:9493.

31. Li N, Yang T, Yu WQ, Liu H. Is waist-to-height ratio superior to body mass index and waist circumference in predicting the incidence of hypertension? Ann Nutr Metab 2019;74:215-23.

32. Jeon J, Jung KJ, Jee SH. Waist circumference trajectories and risk of Type 2 diabetes mellitus in Korean population: The Korean genome and epidemiology study (KoGES). BMC Public Health 2019;19:741.

33. Hajian-Tilaki K, Heidari B. Is waist circumference a better predictor of diabetes than body mass index or waist-to-height ratio in Iranian adults? Int J Prev Med 2015;6:5.

34. Adegbija O, Hoy WE, Wang Z. Corresponding waist circumference and body mass index values based on 10-year absolute Type 2 diabetes risk in an Australian Aboriginal community. BMJ Open Diabetes Res Care 2015;3:e000127.

35. Brenner DR, Tepylo K, Eny KM, Cahill LE, El-Sohemy A. Comparison of body mass index and waist circumference as predictors of cardiometabolic health in a population of young Canadian adults. Diabetol Metab Syndr 2010;2:28

36. Hou X, Lu J, Weng J, Ji L, Shan Z, Liu J, et al. Impact of waist circumference and body mass index on risk of cardiometabolic disorder and cardiovascular disease in Chinese adults: A national diabetes and metabolic disorders survey. PLoS One 2013;8:e57319.

37. Alberti KG, Zimmet P, Shaw J, IDF Epidemiology Task Force Consensus Group. The metabolic syndrome a new worldwide definition. Lancet 2005:366:1059-62

38. Grundy SM, Cleeman JI, Daniels SR, Donato KA, Eckel RH, Franklin BA, et al. Diagnosis and management of the metabolic syndrome: An American Heart Association/national heart, lung, and blood institute scientific statement. Circulation 2005;112:2735-52

39. Agnoli C, Sieri S, Ricceri F, Giraudo MT, Masala G, Assedi M, et al. Adherence to a Mediterranean diet and long-term changes in weight and waist circumference in the EPIC-Italy cohort. Nutr Diabetes 2018;8:22.

40. Bendall CL, Mayr HL, Opie RS, Bes-Rastrollo M, Itsiopoulos C, Thomas CJ. Central obesity and the Mediterranean diet: A systematic review of intervention trials. Crit Rev Food Sci Nutr 2018;58:3070-84.

41. Paula Bricarello L, Poltronieri F, Fernandes R, Retondario A, de Moraes Trindade BS, de Vasconcelos FA. Effects of the Dietary Approach to Stop Hypertension (DASH) diet on blood pressure, overweight and obesity in adolescents: A systematic review. Clin Nutr ESPEN 2018;28:1

42. Makris A, Foster GD. Dietary approaches to the treatment of obesity. 
Psychiatr Clin North Am 2011;34:813-27.

43. Daly P, Pace T, Berg J, Menon U, Szalacha LA. A mindful eating intervention: A theory-guided randomized anti-obesity feasibility study with adolescent Latino females. Complement Ther Med 2016;28:22-8.

44. Ard JD, Miller G, Kahan S. Nutrition interventions for obesity. Med Clin North Am 2016;100:1341-56.

45. Smethers AD, Rolls BJ. Dietary management of obesity: Cornerstones of healthy eating patterns. Med Clin North Am 2018;102:107-24.

46. An J, Yoon SR, Lee JH, Kim H, Kim OY. Importance of adherence to personalized diet intervention in obesity related metabolic improvement in overweight and obese Korean adults. Clin Nutr Res 2019:8:171-83.

47. Jakicic JM, Rogers RJ, Davis KK, Collins KA. Role of physical activity and exercise in treating patients with overweight and obesity. Clin Chem 2018:64:99-107

48. Philippou Ch, Andreou E, Menelaou N, Hajigeorgiou P, Papandreou D. Effects of diet and exercise in 337 overweight/obese adults. Hippokratia 2012;16:46-50.

49. Gordeladze JO. Hidetaka Hamasaki. In: Physical Activity and Obesity in Adults, Adiposity Epidemiology and Treatment Modalities. London: Intech Open; 2017. Available from: https:// www.intechopen.com/books/adiposity-epidemiology-and-treatmentmodalities/physical-activity-and-obesity-in-adults. [Last accessed on 2017 Mar 15]

50. Thenmozhi P. Priya T. Factors contributing for noncompliance of follow-up care among post cardiac patients. Int J Pharm Pharm Sci 2019;11:22-5.

51. Nkeiruka GO, Chinwe VU, Mattew JO. Prescription pattern of cardiovascular and/or antidiabetic drugs in Abuja district hospitals. Int $\mathbf{J}$ Pharm Pharm Sci 2019;11:21-7.

52. Management of Obesity. A National Clinical Guideline. Edinburgh (Scotland): Scottish Intercollegiate Guidelines Network (SIGN); 2010. Available from: https://www.sign.ac.uk/assets/sign115.pdf.

53. Jacobsen DJ, Bailey BW, LeCheminant JD, Hill JO, Mayo MS, Donnelly JE. A comparison of three methods of analyzing post-exercise oxygen consumption. Int J Sports Med 2005;26:34-8.

54. Jakicic JM, Winters C, Lang W, Wing RR. Effects of intermittent exercise and use of home exercise equipment on adherence, weight loss, and fitness in overweight women: A randomized trial. JAMA 1999;282:1554-60

55. Church TS, LaMonte MJ, Barlow CE, Blair SN. Cardiorespiratory fitness and body mass index as predictors of cardiovascular disease mortality among men with diabetes. Arch Intern Med 2005; $165: 2114-20$

56. Farrell SW, Braun L, Barlow CE, Cheng YJ, Blair SN. The relation of body mass index, cardiorespiratory fitness, and all-cause mortality in women. Obes Res 2002;10:417-23.

57. Sui X, LaMonte MJ, Laditka JN, Hardin JW, Chase N, Hooker SP, et al. Cardiorespiratory fitness and adiposity as mortality predictors in older adults. JAMA 2007;298:2507-16.

58. Rankinen T, Church TS, Rice T, Bouchard C, Blair SN. Cardiorespiratory fitness, BMI, and risk of hypertension: The HYPGENE study. Med Sci Sports Exerc 2007;39:1687-92

59. Wing RR, Jakicic J, Neiberg R, Lang W, Blair SN, Cooper L, et al. Fitness, fatness, and cardiovascular risk factors in Type 2 diabetes: Look ahead study. Med Sci Sports Exerc 2007;39:2107-16.

60. Jakicic JM, Egan CE, Fabricatore AN, Gaussoin SA, Glasser SP, Hesson L, et al. Change in cardiorespiratory fitness and influence on diabetes control and CVD risk factors in adults with Type 2 diabetes: 4-year results from the Look AHEAD Trial. Diabetes Care 2013;36:1297-303

61. Cameron N, Godino J, Nichols JF, Wing D, Hill L, Patrick K. Associations between physical activity and BMI, body fatness, and visceral adiposity in overweight or obese Latino and non-Latino adults. Int J Obes (Lond) 2017;41:873-7.

62. Loprinzi PD, Cardinal BJ. Association between biologic outcomes and objectively measured physical activity accumulated in $\geq$ 10 -minute bouts and $<10$-minute bouts. Am J Health Promot 2013;27:143-51

63. Wolff-Hughes DL, Fitzhugh EC, Bassett DR, Churilla JR. Total activity counts and bouted minutes of moderate-to-vigorous physical activity: Relationships with cardiometabolic biomarkers using 2003-2006 NHANES. J Phys Act Health 2015;12:694-700.

64. Creasy SA, Rogers RJ, Davis KK, Gibbs BB, Kershaw EE, Jakicic JM. Effects of supervised and unsupervised physical activity programmes for weight loss. Obes Sci Pract 2017;3:143-52.

65. Polzien KM, Jakicic JM, Tate DF, Otto AD. The efficacy of a technology-based system in a short-term behavioral weight loss intervention. Obesity (Silver Spring) 2007;15:825-30

66. Shuger SL, Barry VW, Sui X, McClain A, Hand GA, Wilcox S, et al. Electronic feedback in a diet- and physical activity-based lifestyle intervention for weight loss: A randomized controlled trial. Int J Behav Nutr Phys Act 2011;8:41.

67. Pellegrini CA, Verba SD, Otto AD, Helsel DL, Davis KK, Jakicic JM. The comparison of a technology-based system and an in-person behavioral weight loss intervention. Obesity (Silver Spring) 2012;20:356-63

68. Rogers RJ, Lang W, Gibbs BB, Davis KK, Burke LE, Kovacs SI, et al. Comparison of a technology-based system and in-person behavioral weight loss intervention in adults with severe obesity. Obes Sci Pract 2016;2:3-12.

69. LeFevre ML, U.S. Preventive Services Task Force. Behavioral counseling to promote a healthful diet and physical activity for cardiovascular disease prevention in adults with cardiovascular risk factors: U.S. Preventive Services Task Force Recommendation Statement. Ann Intern Med 2014;161:587-93.

70. US Preventive Services Task Force, Grossman DC, BibbinsDomingo K, Curry SJ, Barry MJ, Davidson KW, et al. Behavioral counseling to promote a healthful diet and physical activity for cardiovascular disease prevention in adults without cardiovascular risk factors: US preventive services task force recommendation statement. JAMA 2017:318:167-74

71. Siu AL, U S Preventive Services Task Force. Screening for abnormal blood glucose and Type 2 diabetes mellitus: U.S. preventive services task force recommendation statement. Ann Intern Med 2015;163:861-8

72. Sniehotta FF, Evans EH, Sainsbury K, Adamson A, Batterham A, Becker $\mathrm{F}$, et al. Behavioural intervention for weight loss maintenance versus standard weight advice in adults with obesity: A randomised controlled trial in the UK (NULevel Trial). PLoS Med 2019;16:e1002793.

73. Resnicow K, Teixeira PJ, Williams GC. Efficient allocation of public health and behavior change resources: The "difficulty by motivation" matrix. Am J Public Health 2017;107:55-7.

74. Dombrowski SU, O'Carroll RE, Williams B. Form of delivery as a key "active ingredient" in behaviour change interventions. Br J Health Psychol 2016;21:733-40

75. Griffiths F, Lindenmeyer A, Powell J, Lowe P, Thorogood M. Why are health care interventions delivered over the internet? A systematic review of the published literature. J Med Internet Res 2006;8:e10.

76. Michie S, West R. A Guide to Development and Evaluation of Digital Behaviour Change Interventions in Healthcare. UCL Centre for Behaviour Change Monograph. Bream, Silverback Publishing; 2016. Available from: https://www.silverbackpublishing.org/products/cbcmonograph-1

77. Webb TL, Joseph J, Yardley L, Michie S. Using the internet to promote health behavior change: A systematic review and metaanalysis of the impact of theoretical basis, use of behavior change techniques, and mode of delivery on efficacy. J Med Internet Res 2010;12:e4.

78. Hutchesson MJ, Rollo ME, Krukowski R, Ells L, Harvey J, Morgan PJ, et al. eHealth interventions for the prevention and treatment of overweight and obesity in adults: A systematic review with metaanalysis. Obes Rev 2015;16:376-92.

79. Sherrington A, Newham JJ, Bell R, Adamson A, McColl E, AraujoSoares V. Systematic review and meta-analysis of internet-delivered interventions providing personalized feedback for weight loss in overweight and obese adults. Obes Rev 2016;17:541-51.

80. Colon-Gonzalez F, Kim GW, Lin JE, Valentino MA, Waldman SA. Obesity pharmacotherapy: What is next? Mol Aspects Med 2013;34:71-83.

81. Cheung BM, Cheung TT, Samaranayake NR. Safety of antiobesity drugs. Ther Adv Drug Saf 2013;4:171-81.

82. Hocking S, Dear A, Cowley MA. Current and emerging pharmacotherapies for obesity in Australia. Obes Res Clin Pract 2017;11:501-21.

83. Floriana EI, Simona N, Oana CS, Cornel C. Drug therapy in the treatment of obesity. Rom J Diabetes Nutr Metab Dis 2016;3:415-22.

84. Jackson VM, Breen DM, Fortin JP, Liou A, Kuzmiski JB, Loomis AK, et al. Latest approaches for the treatment of obesity. Expert Opin Drug Discov 2015;10:825-39.

85. Chatzigeorgiou A, Kandaraki E, Papavassiliou AG, Koutsilieris M. Peripheral targets in obesity treatment: A comprehensive update. Obes Rev 2014;15:487-503. 
86. Ali KF, Shukla AP, Aronne LJ. Bupropion-SR plus naltrexone-SR for the treatment of mild-to-moderate obesity. Expert Rev Clin Pharmacol 2016;9:27-34

87. Zhang ZY, Wang MW. Obesity, a health burden of a global nature. Acta Pharmacol Sin 2012;33:145-7.

88. American Diabetes Association. 7. obesity management for the treatment of Type 2 diabetes. Diabetes Care 2017;40:S57-S63.

89. Frühbeck G. Bariatric and metabolic surgery: A shift in eligibility and success criteria. Nat Rev Endocrinol 2015;11:465-77.

90. Wolfe BM, Kvach E, Eckel RH. Treatment of obesity: Weight loss and bariatric surgery. Circ Res 2016;118:1844-55.

91. Schroeder R, Harrison TD, McGraw SL. Treatment of adult obesity with bariatric surgery. Am Fam Physician 2016;93:31-7.

92. Buchwald H, Estok R, Fahrbach K, Banel D, Sledge I. Trends in mortality in bariatric surgery: A systematic review and meta-analysis. Surgery 2007; 142:621-32.

93. Maggard MA, Shugarman LR, Suttorp M, Maglione M, Sugerman HJ,
Livingston EH, et al. Meta-analysis: Surgical treatment of obesity. Ann Intern Med 2005;142:547-59.

94. Encinosa WE, Bernard DM, Du D, Steiner CA. Recent improvements in bariatric surgery outcomes. Med Care 2009;47:531-5.

95. Longitudinal Assessment of Bariatric Surgery (LABS) Consortium, Flum DR, Belle SH, King WC, Wahed AS, Berk P, et al. Perioperative safety in the longitudinal assessment of bariatric surgery. N Engl J Med 2009;361:445-54.

96. Birkmeyer NJ, Dimick JB, Share D, Hawasli A, English WJ, Genaw J, et al. Hospital complication rates with bariatric surgery in Michigan. JAMA 2010;304:435-42.

97. Finks JF, Kole KL, Yenumula PR, English WJ, Krause KR, Carlin AM, et al. Predicting risk for serious complications with bariatric surgery: Results from the Michigan Bariatric Surgery Collaborative. Ann Surg 2011;254:633-40.

98. Arterburn DE, Courcoulas AP. Bariatric surgery for obesity and metabolic conditions in adults. BMJ 2014;349:g3961. 